\title{
Akademik Başarıya İlişskin Bilişsel Çarpıtmalar Ölçeğinin (ABİBÇÖ) Geliştirilmesi
}

\section{The Development of Cognitive Distortions Scale Related to Academic Achievement (CDS-AA)}

\begin{abstract}
İdris KAYA*
Öz: Bu çalışmada, lise öğrencilerinin akademik başarıya ilişkin bilişsel çarpıtmalarını ölçecek bir aracın geliştirilmesi ve psikometrik özelliklerinin incelenmesi amaçlanmıştır. Araştırmanın çalışma grubu açımlayıcı faktör analizi için $340(\overline{\mathrm{X}}=16,28 ; \mathrm{Sd}=1,07)$; doğrulayıcı faktör analizi için $218(\overline{\mathrm{X}}=15,8 ; \mathrm{Sd}=$ 1,40 ), test tekrar test güvenirliği için 48 olmak üzere toplam 606 kişiden oluşmaktadır. Ölçeğin geliştirilme sürecinde; öğrenci görüşmelerinden, literatürden ve uzman görüşlerinden hareketle 52 maddeli bir forma ulaşılmıştır. Elde edilen form üzerinde ilk olarak açımlayııı faktör analizi (AFA) yapılmıștır. AFA ve uzman görüşleri çerçevesinde 27 madde araçtan çıkarılarak toplam varynasın \%50, 87'sini açılayan dört faktörlü, 25 maddeli bir form elde edilmiştir. Ulaşılan dört faktörlü yapının model uyumunu incelemek için farklı bir çalışma grubu ile doğrulayıcı faktör analizi (DFA) yapılmış ve elde edilen sonuçlar $\left(X^{2} / \mathrm{sd}=\right.$ 2,29 ; $\mathrm{RMSEA}=.08 ; \mathrm{CFI}=.95 ; \mathrm{NNFI}=.95 ; \mathrm{SRMR}=.08$ ) ölçeğin model veri uyumunun iyi düzeyde olduğunu göstermiștir. Araçta başarısızlığ 1 felaketleștirme ifadelerini içeren boyut "Felaketleștirme"; kişisel değerini akademik başarı üzerinden tanımlayan maddeleri içeren boyut "Benlik değeri" başarı veya başarısızlığı kendi dışındaki etmenlerde arayan ifadeleri içeren boyut "Dışa atıf" başarıya dair katı ve yüksek standartları içeren boyut ise "Mükemmeliyetçilik" olarak isimlendirilmiştir. Ölçeğin güvenirlik analizleri sonucunda elde edilen Cronbach's Alfa iç tutarlılık kat sayısı (.89), test tekrar test güvenirliği (.89) ve yapısal güvenirlik (.94) analizi sonuçları ölçeğin yeterli güvenirlik değerlerine sahip olduğunu göstermiştir. Elde edilen bulgular 25 maddeden oluşan ABİBÇÖ'nün lise öğrencilerinin akademik başarıya ilişkin bilişsel çarpıtmalarını değerlendirmede geçerli ve güvenilir bir ölçme aracı olduğu göstermiştir.

Anahtar Kelimeler: Akademik başarı, bilişsel çarpıtma, ölçek geliştirme
\end{abstract}

\begin{abstract}
The aim of this study is to develop the scale to assess cognitive distortions of high school students related to academic achievement and test its psychometric properties. The study group of the research, 340 for the exploratory factor analysis $(\overline{\mathrm{X}}=16,28 ; \mathrm{Sd}=1,07) ; 218$ for the confirmatory factor analysis $(\overline{\mathrm{X}}=$ 15,$8 ; \mathrm{Sd}=1,40$ ) and 48 for the test retest reliability, is made up of 606 people (334 female, 269 male). During the development process of the scale; from student interviews, literature and expert opinions, a 52item form was obtained. Firstly, exploratory factor analysis (EFA) was performed on the 52 items form. As part of the EFA and expert opinions, 27 items were removed from the tool and a four-factor, 25 -item form was obtained explaining $50.87 \%$ of the total variance. The next, confirmatory factor analysis (CFA) was carried out and the findings $\left(X^{2} / \mathrm{sd}=2.29\right.$; RMSEA $\left.=.08 ; \mathrm{CFI}=.95 ; \mathrm{NNFI}=.95 ; \mathrm{SRMR}=.08\right)$ showed that the four factor model has sufficient fit-indexes. The dimension of the tool that includes the statement of catastrophy of failure is called "Catastrophizing." while the dimension define the personal value through academic achievement is called "Self- value". The third dimension of the scale is called "Outer attribution" since it is including statements that attributes the achievement or failure to the outer factors and lastly the dimension contains the rigid and high standards of achievement is called "Perfectionism". Cronbach's alfa internal consistency coefficient (.89), test retest reliability (.89) and structural reliability (.94) analyses proved that the scale had adequate reliability values. The findings obtained from all the analyses above revealed that this scale of 25 items is a valid and reliable measurement tool to evaluate the cognitive distortions of high school students related to academic achievement.
\end{abstract}

Keywords: Academic achievement, cognitive distortions, scale development

\footnotetext{
* Dr. Öğr.Üyesi, Hatay Mustafa Kemal Üniversitesi, Eğitim Fakültesi, Hatay-Türkiye, ORCID: 0000-0001-9562-3347 e posta: id.kaya@gmail.com
} 


\section{Giriş}

Günümüzde depresyon, anksiyete bozukluklarının yanı sıra şizofreniden ve kişilik bozukluklarına kadar geniş bir yelpazede bir çok ruhsal problemin tedavisinde kullanılan bilişsel temelli terapi modellerinin 1960/70'li yıllardan itibaren Ellis ve Beck tarafından öne çıkarılmaya başlandığ söylenebilir (Butler, Chapman, Forman ve Beck, 2006; Sungur, 1997). İnsanların duygu ve davranışlarının onların öznel yaşantılarından çok, o yaşananlara ilişkin düşünceleri ile ilgili olduğunu kabul eden bu ruh sağlığı modelleri, psikolojik rahatsızlıkların altında yatan temel mekanizmanın bireyin çarpıtmış ve işlevsel olmayan düşünceleri olduğunu kabul ederler (Beck, 2006). Bu noktada bilişsel temelli tedavi modellerinin "başımızdan geçenlerin değil aklımızdan geçenlerin" bizi rahatsız edebileceğini kabul ettiği söylenebilir. Bu modellerden biri olan Akılcı Duygusal Davranış Terapi (Ellis, 1976, 1979, ss. 1-89) insanların olaylar karşısında akılcı olmayan düşünüş tarzlarının, bir diğeri olan Bilişsel Terapi (Beck, Lıese ve Najavits, 2005) ise olaylara ilişkin bilişsel çarpıtmaların bireyin yaşamını zorlaştıran duygular yaşamasına neden olacağını ifade eder. Bu kapsamda düşünceyi merkeze alan bu tedavi modelleri kişinin işlevsel olmayan düşünüş tarzının belirlenip, çeşitli müdahalelerle bu düşüncelerin değişmesi ile kişinin psikolojik iyi oluşunun sağlanabileceğini belirtirler (Beck, 2006). Bilişsel temelli yaklaşımları referans alarak ruh sağlığı hizmeti veren profesyoneller, bazı duygusal sorunlarda birbirine benzer düşünce örüntülerinin olduğunu gözlemler ve buradan hareketle de bireyin duygusal zorluklar yaşamasına neden olan bu düşünce sistemlerini zamanla kategorize etmeye başlarlar (Dobson ve Dozois, 2010; Leahy, 2007). Beck'in bilişsel modeli çerçevesinde işlevsel olmayan düşünceler kategorize ederek bilişsel çarpıtmalar şeklinde sınıflandırılmıştır.

$\mathrm{Bu}$ çalışma Beck'in bilişsel terapi modeli çerçevesinde tanımlanan bilişsel çarpıtmalara dayanmaktadır. Bilişsel çarpıtma, kişinin belirgin bir duruma özgü çoğunlukla hatalı şekilde işleyen düşünme ve algılama biçimi olarak ifade edilebilir. Çok büyük oranda kişi bu düşünce biçimlerinin gerçekliğini sınamadan ve doğruluğuna dair yeteri kanıt elde etmeden bunları olduğu kabul eder. Bilişsel terapi literatüründe farklı isimlendirme veya sınıflamalar olsa da en yaygın tanımlanan bilişsel çarpıtmalar "zihin okuma", "felaketleştirme", "etiketleme", "aşırı genelleme", "kişiselleştirme", "ya hep ya hiç", "keyfi çıkarsama", "seçici soyutlama", "-meli -malı" "büyütme, küçültme", "olumsuza odaklanma", "duygusal çıkarsama" şeklindedir (Childress ve Burns, 1981; Dryden, David ve Ellis, 2010.)

Sınavlara giren öğrenciler bazen sınavlara, sınanmanın gerçek anlamından uzaklaşan anlamlara verirler. Özellikle sınavlarda elde edilen puanın kişinin değerini yansıttığ başarısızlığın "aptal, kötü evlat" gibi özellikleri beraberinde getireceği gibi düşüncelerle sınavı bir kişilik ölçümüne dönüştürmektedirler. Bu toptancı anlam ve inanışlar gerçekçi ve akılc1 ölçütlerden oldukça uzaktır çünkü sınavlar kişiliği değil bilgiyi ölçer. Kişi başarıya olduğundan çok daha yüksek bir anlam yüklediğinde ya hiç hata yapmamak için kendini aşırı zorlayacak ya da hata yapmamak adına yapabileceği şeyleri bile yapmamaya başlayacaktır. Bununla birlikte kişi kendisini bir defa başarılı olarak atfettikten sonra bu sıfatı kaybetmemek için yoğun bir çaba sarf etmeye başlayabilir. Bu durum da onu sinirli, gergin, huzursuz bir hale getirebilir ve "başarıl1" sıfatını kaybettiğini düşündüğünde çöküntü/depresyon duygu durumuna geçebilir (Özer, 1990). Uşaklı ve Yapıcı (2001) sınav kaygısı ile ilgili yaptıkları çalışmada kaygının bilişsel boyutunda öğrencilerde "sınavlarda başarılı olamayacağım, sınav sonunda her şey berbat olacak, bildiğim her şeyi unutacağım, kendimi yetersiz görüyorum, evdekilerin yüzüne nasıl bakarım, sınavda başarısız olursam bir daha asla düzeltemem" gibi bazı düşüncelerin olduğunu belirlemiş̧lerdir.

Türkiye ve dünyada yapılan birçok çalışmada bilişsel çarpıtmalar ile akademik başarı ve bireyin psikolojik özellikleri arasında ilişkiler olduğu görülmektedir. Aydın (1990) üniversite ögrencilerinin depresyon düzeylerinin akademik ortalama ve otomatik düşünceler tarafından yordandığını, Özdel ve diğerleri (2014) bilişsel çarpıtmalar ile depresyon ve sürekli-durumluk kaygı arasında, Ağır (2007) bilişsel çarpıtma ile umutsuzluk ve düşük problem çözme becerisi arasında ilişki olduğunu, Savi-Cakar (2014) ise otomatik düşüncelerin umutsuzluk düzeyi üzerinde anlamlı bir yordayıcı olduğunu belirlemiştir. Bunlarla birlikte ergenlerin sınav kaygısı ile akılcı olmayan düşünüş tarzı arasında ilişki olduğunu gösteren çalışmalar da bulunmaktadır (Boyacioglu ve Kucuk, 2011; Güler ve Çakir, 2013). Putwain, Connors ve Symes (2010) 
yaptıkları çalışmada ise sınav kaygısı ile akademik başarı arasında bilișsel çarpıtmaların tam aracılık etkisi olduğunu tespit etmişlerdir. Tüm bu çalışmalar ergenlerin akademik başarıya ilişkin bilişsel çarpıtmalarının belirlenmesinin önemli bir ihtiyaç olduğunu göstermektedir.

Türkiye'de öğrencilerin yükseköğretime geçebilmek için başarılı olmak zorunda oldukları sınavları düzenleyen Ölçme, Seçme ve Yerleştirme Merkezi (OSYM) (2017) verilerine göre iki milyonu aşkın öğrenci yükseköğretime geçiş sınavlarına girmektedir. Milli Eğitim Bakanlığı MEB (2016) verilerine göre ise üç milyondan fazla öğrencinin akademik eğitim yapan liselerde öğrenim görmektedir. Bu veriler, akademik başarının öğrencilerin ve ailelerinin yaşamlarındaki önemli konulardan biri olduğunun göstergesi olarak kabul edilebilir. Özellikle başarının karşılaştırılmalı olarak değerlendirildiği eğitim kademlerinde birçok öğrencinin hayatında başarı daha büyük bir yer tutmaya başlamakta ve bunun için harcanan çaba ve dolayısıyla başarıya dair kaygılar artmaktadır. Öğrencilerin temel eğitimden orta öğretime, orta öğretimden yükseköğretime geçişlerinin büyük oranda sınav puanları çerçevesinde belirlendiği ülkelerden biri olan Türkiye'de akademik başarıya öğrenci, aile ve okul tarafından atfedilen önem oldukça yüksek olduğu söylenebilir.

Bilişsel Terapi ve Akılcı Duygusal Davranışçı Terapi çerçevesinde düşünceleri ölçmeye yönelik birçok ölçme aracı geliştirilmiştir. Ancak, Fonksiyonel olmayan tutumlar ölçeği (Savaşır ve Şahin, 1997), Otomatik düşünceler ölçeği (Aydın ve Aydın, 1990) İlişkilerle ilgili bilişsel çarpıtmalar ölçeği (Hamamcı ve Büyüköztürk, 2003) Akılcı olmayan inançlar ölçeği (Türküm, 2016), Anne babaları akılcı olmayan inançları ölçeği (Kaya ve Hamamc1, 2011) Meslek seçimine ilişkin akılcı olmayan inançlar ölçeği (Erdem ve Bilge, 2008) Romantik ilişkilerde akılcı olmayan inançlar ölçeği (Sarı ve Korkut Owen, 2015) gibi bilişsel çarpıtmalar veya akılcı olmayan inançları ölçmeye yönelik geliştirilmiş birçok ölçme aracına olmasına rağmen doğrudan ergenlerin akademik başarıya ilişkin bilişsel çarpıtmalarını ölçmeye yönelik herhangi bir ölçme aracına rastlanmamıştır. İncelenen ölçekler içerisinde Özdel ve diğerleri, (2014) tarafından kişiler arası ilişkiler ve kişisel başarıya ilişkin bilişsel çarpıtmaları ölçmeye yönelik geliştirilen ölçme aracının kişisel başarı alt boyutu, başarıya ilişkin bilișsel çarpıtmaları ölçüyor olmakla beraber genel tanımlamalar (iş veya okul yaşamı gibi) içerdiği, doğrudan akademik başarıya odaklanmadığ 1 ve ölçek yetişkin popülasyona yönelik geliştirildiğinden, ergenler üzerinde doğrudan akademik başarıya ilişkin bilişsel çarpıtmaları ölçecek bir ölçme aracına gereksinim olduğu kanaatine varılmıştır.

$\mathrm{Bu}$ çalışmanın amacı orta öğretime devam eden öğrencilerin akademik başarıya ilişkin bilişsel çarpıtmalarını değerlendirecek standart bir ölçme aracı geliştirmektedir. Geliştirilecek bu aracın öğrencilerin spesifik olarak başarıya ilişkin bilişsel çarpıtmalarının anlaşılmasını ve dolayısıyla da müdahalesini kolaylaştıracağı ön görülmektedir. Bununla birlikte aracın, akademik başarıya ilişkin bilişsel çarpıtmalara yönelik önleyici ve iyileştirici ruh sağlığı hizmetlerini ve konuya dair kuramsal çalışmaları kolaylaştırabileceği düşünülmektedir.

\section{Yöntem}

\section{Ölçek maddelerinin geliştirilme süreci}

ABİBÇÖ'nün geliştirilme sürecinde ilk olarak yükseköğretime giriş sınavlarına hazırlanan öğrenciler ile bireysel ve grup olarak görüşmeler yapılmış ve öğrencilerin sınavlara yükledikleri anlam anlaşılmaya çalışılmıştır. Bu görüşmelerde öğrencilere başarı veya başarısılılı̆ın kendileri için ne anlam ifade ettiği, başarılı veya başarısız olurlarsa bunun yaşantılarını nasıl etkileyeceği, çevrelerindeki kişilerden nasıl tepkiler alacaklarını tahmin ettikleri gibi yarı yapılandırılmış sorular yöneltilmiş ve öğrencilerin verdikleri tepkilerde gözlenen bilişsel çarpitmalar not edilmiştir. Bu ilk aşamada yaklaşık 40 öğrenci ile görüşme yapılmıştır. Madde yazımının ikinci aşamasında bilişsel terapinin bilişsel çarpıtmalara ilişkin literatürü incelenmiş ve bilişsel çarpıtma olarak tanımlanan düşünme tarzları akademik başarıya adapte edilerek ölçek maddeleri yazılmıştır. Sürecin üçüncü aşamasında daha önce farklı konularda bilişsel çarpıtmaları ve akılcı olmayan inançları ölçmeye yönelik geliştirilmiş ölçekler incelenmiş ve madde yazımında bu ölçeklerin maddelerinden de yararlanılmıştır. Tüm bu işlemlerin sonunda 55 maddeli bir ölçek deneme formu oluşmuştur. 
Oluşturulan deneme formundaki maddelerinin akademik başarıya ilişkin bilişsel çarpıtmaları yansıtıp yansıtmadığını belirlemek amacıyla form üç uzmana gönderilmiştir. Uzmanlar, rehberlik ve psikolojik danışma alanında çalışan, daha önce ölçek geliştirme sürecinde bulunmuş, bilişsel terapi ile ilgili çalışmaları olan akademisyenlerdir. Uzmanlardan ölçeğin ön formundaki her bir maddeyi, ölçeğin ölçme amacına uygun olup olmadığı bir başka ifade ile akademik başarıya ilişkin bilişsel çarpıtmaları yansıtıp yansıtmadığını üçlü bir dereceleme ile (bilişsel çarpıtma olarak uygun-kısmen uygun-uygun değil) değerlendirmeleri istenmiştir. Bu görüş alma sürecinde uzmanlardan kısmen uygun buldukları ve uygun bulmadıkları maddelere yönelik önerilerinin veya yeni madde önerilerinin olup olmadığı da sorulmuştur. Uzman görüşü çerçevesinde ön deneme formundan üç madde, üç uzmanın üç tarafindan da olumsuz puanlanması neticesinde formdan çıkarılmış ve 26 madde düzeltilerek formun nihai hali oluşmuştur. Uzman görüşünün ardından deneme formu dil yönünden (anlatım, anlaşılırlık, yazım, imla) incelenmek üzere iki Türkçe öğretmenine inceletilmiş ve Türkçe öğretmenlerinin önerileri göz önüne alınarak bir maddede düzenleme yapılmıştır. Oluşturulan ölçek deneme formundaki maddelerin lise öğrencileri tarafından anlaşılıp anlaşılmayacağını belirlemek için 28 öğrenciden oluşan bir sınıfa uygulanmış ve maddeleri anlaşılırlık açısından incelemeleri istenmiştir. Bu öğrencilerden gelen dönütler maddelerin anlaşılır olduğu sonucuna ulaşılmıştır.

\section{Verilerin toplanması}

52 maddeden oluşan ölçek deneme formu Hatay Milli Eğitim Müdürlüğünden alınan izin çerçevesinde Defne ve Antakya ilçelerinde mesleki ve akademik eğitim yapan liselerdeki 9, 10, 11 ve 12. sınıf öğrencilerine uygulanmıştır. Uygulama yapılacak okullardaki psikolojik danışmanlar ile görüşülmüş çalışmanın amacı ve veri toplanırken dikkat edilmesi gerekenler hakkında bilgi verilerek ölçek formları teslim edilmiştir. Psikolojik danışmanlar verileri toplarken sınıflara şahsen girdiklerini çalışmanın amacı, formların nasıl doldurulacağı ve çalışmaya katılımın gönüllülük esasına dayandığını ifade ettiklerini beyan etmişlerdir. Bununla birlikte ölçek formlarının başında çalışmanın amacını, formların nasıl doldurulacağını, çalışmaya katılımın gönüllügüne ilişkin bir yönerge konmuş ve araştırmacıya ulaşmak isterlerse nasıl ulaşabileceğine dair iletişim bilgileri verilmiştir. Açımlayıcı faktör analizi için toplamda 400 ölçek formu ilk çalışma grubuna uygulanmıştır. Açımlayıcı faktör analizi tamamlandıktan sonra 25 maddeden oluşan ölçek formu doğrulayıcı faktör analizi için 300 kişilik ikinci bir çalışma grubuna uygulanmış ve bu uygulamada da daha önce yapıldığı mesleki eğitim yapan ve akademik eğitim yapan okulların bulunması sağlanmıştır.

Veri toplama sürecinde son olarak ölçeğin test tekrar test güvenirliğini belirlemek için akademik eğitim yapan bir okulun 11. sınıfına devam eden 63 öğrenciye 22 gün arayla iki defa uygulanmıştır. Bu işlem esnasında iki uygulama arasında eşleştirme yapabilmek için öğrencilere ölçeğin üzerine bir rumuz/nickname yazmaları istenmiştir.

\section{Verilerin analizi}

Bu çalışmada akademik başarıya ilişkin bilişsel çarpıtmalar ölçeğinin geçerlilik çalışması için açımlayıcı faktör analizi (AFA) ve doğrulayıcı faktör analizi (DFA) yapılmıştır. Açımlayıcı faktör analizi, çok sayıdaki değişkeni daha az sayıda faktöre indirgemek için hangi değişkenlerin diğer değişkenlerden nispeten bağımsız olduğunu keşfetmek amacıyla yapılan istatistiksel yöntemlerdir (Tabachnick ve Fidell, 2015). Geliştirilmek istenen akademik başarıya ilişkin bilişsel çarpıtmalar ölçeğine ait değişkenler arasındaki ortak yapıları/faktörleri belirlemek ve yapı geçerliğine ilişkin veri elde etmek amacıyla ilk AFA kullanılmıştır (Çokluk, Şekercioğlu ve Büyüköztürk, 2010). İkinci aşamada AFA sonucunda elde edilen faktör yapısının farklı bir örneklemde doğrulanıp doğrulanmayacağını belirlemek için DFA yapılmıştır. DFA, bir teorik yapıya bağlı olarak daha önceden belirlenmiş bir hipotezin veya standardize edilmiş bir aracın mevcut veri tarafından doğrulanıp doğrulanmadığının sınanması işlemidir (Byrne, 2010; Kline, 2005; Şimşek, 2007). Verilerin analize uygunluğu Kaiser-Mayer-Olkin (KMO) katsayısı ve Barlett küresellik testi ile güvenirlik değerleri ise Cronbach Alfa, test tekrar test ve yapısal güvenirlik teknikleri ile incelenmiştir. 
Analizler kapsamında ilk olarak oluşan SPSS dosyası, kayıp veriler, uç değerler, normallik ve çoklu bağlantı sorunu açısından incelenmiş olup gerekli tarama ve temizlemeler yapıldıktan sonra analizlere geçilmiştir. Analizlerden açımlayıcı faktör analizi, korelasyon ve güvenirlik analizleri SPSS 20; doğrulayıcı faktör analizi ise LISREL paket programı ile yapılmıştır.

\section{Çalışma grubu}

$\mathrm{Bu}$ çalışmanın ulaşılabilir evreni Hatay şehir merkezinde öğrenim gören lise öğrencilerinden oluşmaktadır. Araştırmanın örneklemi, faktör analizleri için amaçsal örnekleme yöntemlerinden maksimum çeşitlilik yöntemi, test tekrar test çalışması için ise uygun/kazara örnekleme yöntemi ile belirlenmiştir (Büyüköztürk, Çakmak, Akgün, Karadeniz ve Demirel, 2008). Çalışmada maksimum çeşitliliği sağlamak amacıyla okulların farklı sosyo ekonomik düzeyden olmasına, farklı sınıf türlerinden öğrencilerin bulunmasına ve hem akademik eğitim yapan hem de mesleki eğitim (teknik, sağlık, imam hatip gibi) yapan liselerin bulunmasına özen gösterilmiştir. Çalışmada üç faklı örneklem grup ile çalışılmıştır. İlk örneklem gruptan elde edilen verilerle açımlayıcı faktör analizi, ikinci örneklem grupla doğrulayıcı faktör analizi, üçüncü örneklem grupla ise test tekrar test güvenirlik çalışması yapılmıştır. AFA'nın yapmak için 400 form uygulanmaya çalışılmış ancak bu formlardan 365'i geri dönmüş olup dönen formlardan da rastgele doldurma, çok fazla boş bırakma, aşırı uç değerler gibi temizleme işlemi yapıldıktan sonra analizler 340 veri üzerinden analiz yapılmıştır. AFA'nın yapıldığı bu çalışma grubunun 213 'ü $(\% 62,6)$ kadın, 124'ü $(\% 36,5)$ erkek olup grubun yaş ortalamas1 16,28'dir ( $\mathrm{Ss}=1,07)$. AFA sonucu elde edilen yapının farklı bir grupta doğrulanıp doğrulanmayacağının belirlenmesi için ilk analizlerden elde edilen 31 maddeli form, 300 kişiye daha uygulanmaya çalışılmış ve uygulanmadan dönen 252 form üzerinde gerekli temizleme işlemleri yapıldıktan sonra DFA analizleri 218 veri üzerinde yapılmıştır. DFA'nın yapıldığı grubun 96'sı (\%44) kadın, 122'si (\%56) erkek olup grubun yaş ortalaması $15,8^{\prime}$ dir $(\mathrm{Ss}=1,40)$. AFA ve DFA'nın yapıldı 558 kişiden oluşan 316's $(\% 56,6)$ mesleki eğitim yapan okullardan grubun 228'i $(\% 40,9)$ akademik eğitim alan öğrencilerden oluşmaktadır. Öğrencilerin sınıf düzeyine göre dağılımı ise 165'i (\%29,6) 9. sinıf, 158'i (\%28,3) 10. sinıf, 89'u (\%15,9) 11. sinıf, 136's1 (\%24,8) 12. sinif şeklindedir. Faktör analizleri dışında test tekrar test güvenirlik çalışması için 63 on birinci sınıf öğrencisine ölçek iki defa uygulanmış ancak 15 verinin eşleştirilmesi yapılamadığından analiz 48 $(\overline{\mathrm{X}}=16,76 ; \mathrm{Ss}=.43)$ veri üzerinden yapılmıştır.

Faktör analizi çalışmalarında veri toplanan örneklem grubun büyüklüğü yapılacak analizleri etkiyecek önemli bir durumdur. Örneklemin kaç değerden oluşması gerektiği ile ilgili istatistik kaynakları farklı sayıları verseler de genel olarak 300 ve üstü ölçümün yeterli olduğu söylenebilir (Seçer, 2013). Bununla birlikte Kline (2005) faktör analizi için 100-200 arası gözlemin "orta" büyüklükte, 200'ü aşan gözlem sayısının ise "geniş” büyüklükte bir örneklemi yansıttı̆̆ını ifade eder. Bu ölçüler çerçevesinde bu çalışma kapsamında yapılan gerek açımlayıcı gerekse doğrulayıcı faktör analizi için kullanılan veri setinin faktör analizine uygun olduğu görülmektedir. Diğer taraftan çalışma grubunun açımlayıcı faktör analizine uygunluğuna ilişkin diğer bir fikir alabilecek kaynaklardan biri olan $\mathrm{KMO}$ değerinin yüksekliği $(\mathrm{KMO}=.87)$ çalışma grubunun uygunluğunun diğer bir göstergesidir.

\section{Bulgular}

AFA ve DFA için toplanan 617 kişilik verilerin analize uygunluğunu belirlemek için yapılan ön incelemelerde aşırı uç değer gösteren, sistematik olarak hatalı kodlanan veya maddelerin \%5'inden fazlasını boş bırakılan 59 veri analiz dışı bırakılmış, sonrasında kayıp veriler aritmetik ortalama ile doldurulmuştur (Tabachnick ve Fidell, 2015). Çok değişkenli istatistiklerin hemen hemen tümünde normallik, doğrusallık, çoklu bağlantı sorunu ve eşvaryanslılık (homojenlik) sayıltıları aranır. Bu kapsamda istatistiklerin önemli sayıltılarından biri olan normallik varsayımının için ilk olarak değişkenlerden her birinin normalliği Skewness ve Kurtosis değerleri ile incelenmiş ve verilerin normallik varsayımını (-1 ile +1 arasında olma) karşıladığı görülmüştür (Leech, Barrett ve Morgan, 2005). Bununla birlikte verilerin çok değişkenli normal dağılımı ise 
Barlett küresellik testi ile incelenmiş ve verilerin çok değişkenli normallik varsayımını karşıladığ da belirlenmiştir. $\mathrm{Bu}$ kapsamda verilerin çok değişkenli normallik varsayımını karşılaması değişken çiftleri arasındaki ilişkinin doğrusal olduğunu bir kanıt olarak düşünülebilir (Çokluk ve diğerleri, 2010; Leech ve diğerleri, 2005; Tabachnick ve Fidell, 2015). Verilerin çoklu bağlantı sorunu olup olmadığı incelendiğinde ise hiçbir maddenin diğer bir madde ile .85 üstü korelasyon göstermediği belirlenmiş ve bu veriden hareketle verilerin çoklu bağlantı sorunu olmadığı sonucuna ulaşılmıştır (Kline, 2005).

\section{Açımlayıcı faktör analizi (AFA)}

Birinci örneklem grup üzerinde AFA yapılmadan önce toplanan verilerin faktör analizi için uygun olup olmadığına karar vermek için Kaiser-Meyer-Olkin (KMO) katsayısı hesaplanmış, verilerin çok değişkenli normal bir dağılımda olup olmadığı ise Bartlett's anlamlılık düzeyi testi ile incelenmiştir. Tavşancil (2002) ve Field (2009) örneklemden elde edilen verilerin yeterliliğini ölçen KMO değerinin 1'e yaklaştıkça mükemmelleştiğini sıfıra yaklaştıkça ise zayıfladığını ifade ederek 0.50'nin altında bir KMO değerinin kabul edilemez olduğunu bildirirler. Büyüköztürk (2010) ise KMO değerinin 0.60 ve üstü olmasının ve Bartlett's testinin anlamlı çıkmasının faktör analizi için yeterli olduğunu belirtmektedir. Veriler üzerinde yapılan analizlerde KMO değeri 0.87; Bartlett's testinin ise anlamlı olduğu görülmüştür $\left(X^{2}=6844,22 ; \mathrm{p}<.01\right)$. Elde edilen bu değerler verilerin açımlayıcı faktör analizi için uygun olduğunu göstermektedir.

Açımlayıcı faktör analizinde öz değeri bir veya daha büyük olan faktörler önemli faktör olarak kabul edilir (Büyüköztürk, 2010; Can, 2017; Yaşlığlu, 2017). ABİBÇÖ üzerinde yapılan açımlayıcı faktör analizinde 13 faktörün birin üzerinde yük değerine sahip olduğu ve bu faktörlerin toplam varyansın \% 61,72'sini açıkladığı görülmüş̧ür. Pallant (2016) ölçekte yer alması gereken faktör sayısını belirlemede kullanılabilecek yöntemlerden birinin Catell yamaç testi olduğunu ifade eder. Bu testte öz değer grafiğindeki (scree plot) dikey çizginin yatay hale gelmeye başladığı yer faktör sayısı olarak belirlenir. Bu çalışma kapsamında yapılan analizde elde edilen faktör sayısının 13 olması faktör sayısının azaltılması ihtiyacını doğurmuş ve öz değer grafiği (Şekil 1) incelendiğinde dördüncü faktörden sonra grafiğin yatay hale geldiği görüldüğünden analizler dört faktör ile sınırlandırılarak yapılmıştır.

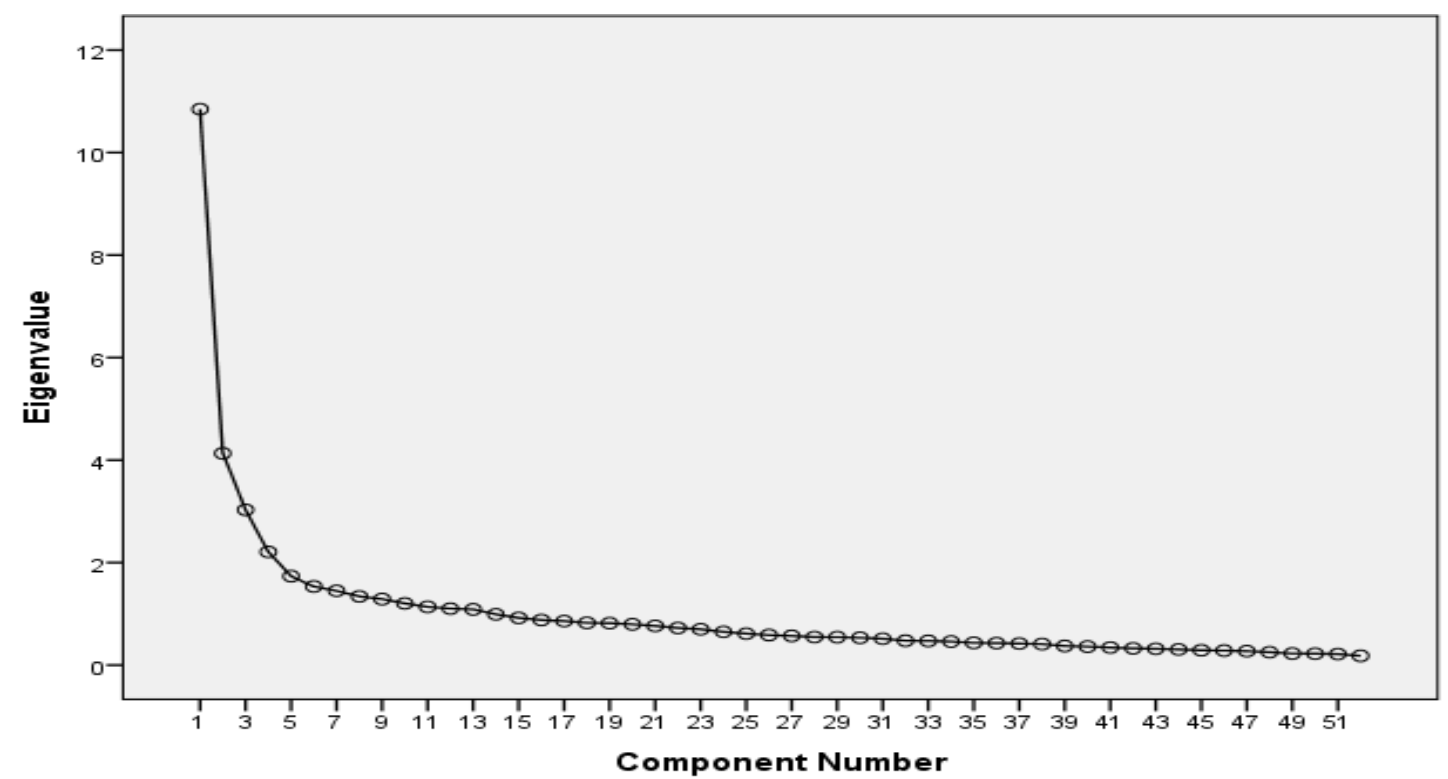

Şekil 1. ABİBÇÖ öz değer grafiğgi (scree plot)

Faktör analizinde, faktörler ilk ortaya çıkarıldığında maddelerin çoğu en fazla yüke sahip en önemli faktörde toplandığı için faktörleri anlamlandırmak oldukça güçleşir ve faktörlerin yorumlanmasına açıklık getirmek için döndürme işlemine gereksinim duyulur (Can, 2017). Bu çalışmada dört faktörlü yapı üzerinde varimax dik döndürme tekniği uygulanarak faktör 
özellikleri belirlenmiștir. Faktör analizinde, faktörler birbirinden bağımsız ise dik döndürme, birbiri ile ilişkili ise eğik döndürme tercih edilir (Saraçli, 2011). Bununla birlikte Büyüköztürk (2002) eğik ve dik döndürme sonucu elde edilen değerlerin birbirine yakın olduğunu ve araştırmacı sonuçların genellenebilirliği ile ilgileniyorsa dik döndürmeyi tercih etmesini önerir. Bu kapsamda bu çalışmada dik döndürme teknikleri içerisinde en sık kullanılan teknik olan varimax (Tavşancil, 2002) tekniği tercih edilmiştir.

Faktör analizinde bir maddenin yer aldığı faktördeki yükünün yüksek olması tercih edilen bir durumdur. Maddenin faktörde kalması için değişken ve faktör arasında en az \% 20 varyansın açıkladığı anlamına gelecek olan faktör yük değerinin .45 ve üstü olması kesme noktası olarak alınabilir (Can, 2017; Tabachnick ve Fidell, 2015). Bununla birlikte ölçme aracındaki her bir maddenin faktör yükünün mümkün olduğunca tek boyutta olması arzu edilen bir durumdur çünkü bu durum maddelerin birbirinden bağımsız yapıları ölçtüğünün bir kanıtıdır. Diğer taraftan bir maddenin birden fazla boyutta yüksek faktör yüküne sahip olması o maddenin binişik olduğu anlamına gelir (Büyüköztürk, 2010; Çokluk ve diğerleri, 2010). Can (2017) ölçek geliştirme sürecinde tutucu davranılmak isteniyor ve maddelerin ölçekten çıkarılması yapısını bozmayacaksa bir maddenin iki faktördeki yükü arasındaki farkın .15 olmasının tercih edilebileceğini ifade eder. Bu çalışma kapsamında faktör yük değerleri .45'in altında olan ve iki faktördeki yük değeri fark1 .15'in altında olan 25 madde $(1,2,4,5,6,7,13,14,16,17,19,21,22,23,24,25,27,29,30,31,35,41,43,46,47)$ ölçekten çıkarılmıştır.

Bir ölçeğin deneme formunda işlemeyen maddeler çıkarılırken maddelerin birer birer çıkarılması ve kesin bir kural olmamakla birlikte madde çıkarma işlemine önce binişik maddelerden başlanması önerilmektedir (Çokluk ve diğerleri, 2010). Bu kapsamda binişiklik düzeyi en yüksekten başlanarak on madde atılmış ve ardından en düşük faktör yükü olan maddelerden başlayarak faktör yükü $.45^{\prime}$ 'in altında olan 15 madde ölçekten çıkarılmış olup toplamda 25 madde ölçme aracından çıkarılmıştır. 27 madde dört faktör ile sınırlandırılarak AFA yapılmış ve oluşan faktörler tekrardan uzman görüşüne sunulmuştur. Uzmanlardan gelen geri bildirimler çerçevesinde iki maddenin (10 ve 40$)$ yer aldığı boyutla uyuşmadığı ifade edildiğinde bu maddeler araçtan çıkarılmıştır. Nihai formda kalan 25 maddeden oluşan dört faktörlü yapının döndürme sonrası yer aldıkları faktördeki yük değerleri, ortak faktör varyansları ve maddelerin ölçeğin geneli ile olan korelasyon değerleri tablo 1'de gösterilmiştir.

Tablo 1.

Maddelerin Yer Aldığı Faktördeki Yük Değerleri, Ortak Faktör Varyansları ve Madde-Toplam Korelasyonları

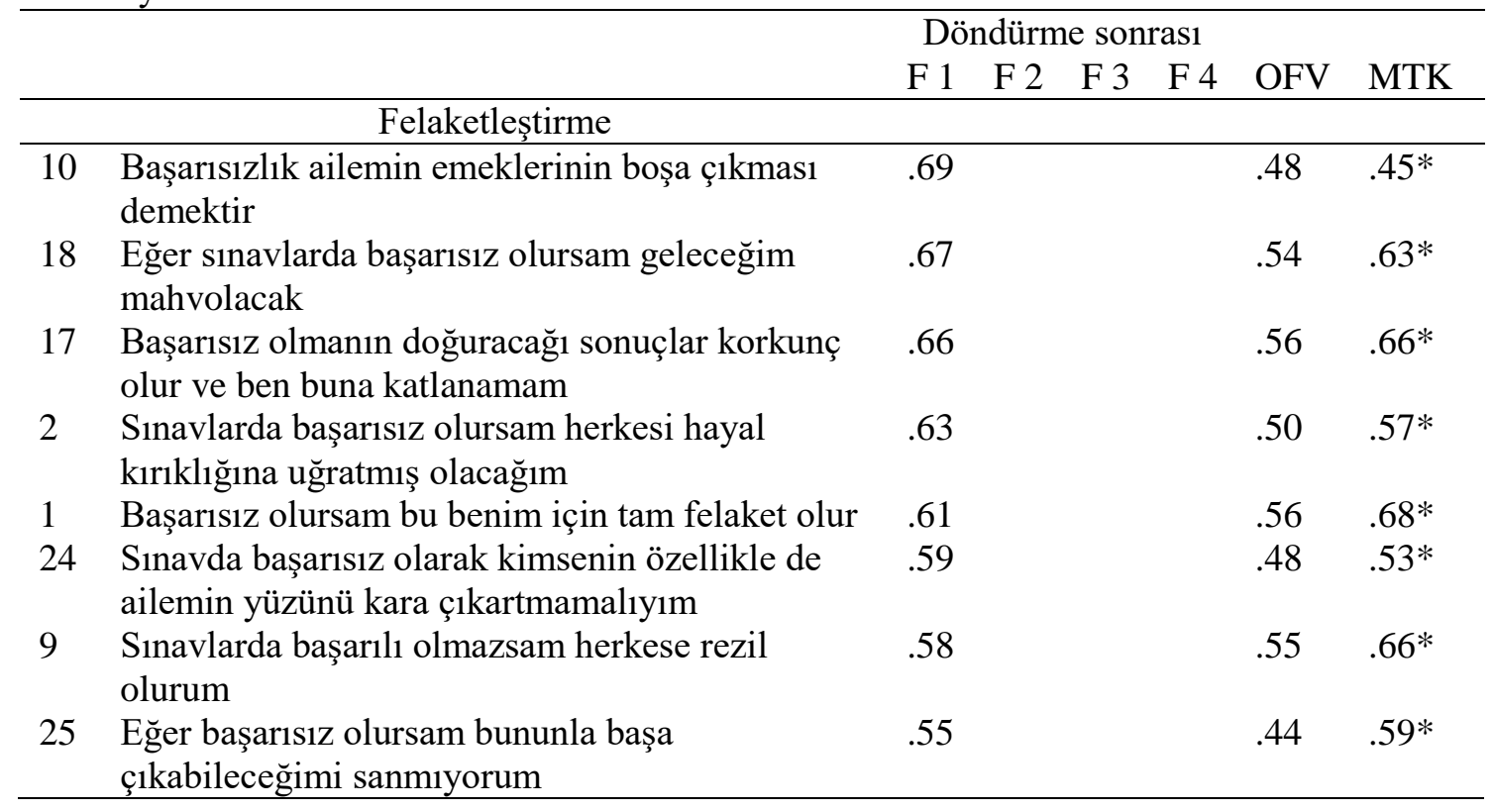




\begin{tabular}{|c|c|c|c|c|c|}
\hline \multicolumn{6}{|c|}{ Benlik değeri } \\
\hline 12 & $\begin{array}{l}\text { Sinavdan yüksek puan alamazsam kimse beni } \\
\text { adam yerine koymaz }\end{array}$ & .79 & & .66 & $.49 *$ \\
\hline 19 & $\begin{array}{l}\text { Eğer sinavlarda başarısız olursam bu benim } \\
\text { değersiz bir insan olduğumu gösterir }\end{array}$ & .77 & & .61 & $.46^{*}$ \\
\hline 20 & $\begin{array}{l}\text { İnsanlar bana sınavlardan aldığım puanlar } \\
\text { ölçüsünde saygı gösterirler }\end{array}$ & .66 & & 49 & $.48 *$ \\
\hline 4 & $\begin{array}{l}\text { İnsanların beni sevmesi için sınavlardan yüksek } \\
\text { puan almalıyım }\end{array}$ & .64 & & .44 & $.40 *$ \\
\hline 11 & $\begin{array}{l}\text { Başarısız olduğumda çevremdeki insanlar benim } \\
\text { aptal olduğu düşünür }\end{array}$ & .64 & & 44 & $.44 *$ \\
\hline 3 & $\begin{array}{l}\text { Sinavlarda başarısız olmam yetersiz bir insan } \\
\text { olduğumu gösterir }\end{array}$ & .52 & & .34 & $.47 *$ \\
\hline \multicolumn{6}{|c|}{ Dişa atıf } \\
\hline 21 & $\begin{array}{l}\text { Başarılı olmak için insanın mutlaka doğuştan } \\
\text { yetenekli olması gerekir }\end{array}$ & & .73 & .55 & $.35^{*}$ \\
\hline 13 & $\begin{array}{l}\text { Ne kadar çalışırsam çalışayım ben asla başarılı } \\
\text { olamam }\end{array}$ & & .67 & .47 & $.30 *$ \\
\hline 5 & $\begin{array}{l}\text { Bazı insanlar başarı konusunda şanslı doğar ama } \\
\text { ben asla onlardan biri değilim }\end{array}$ & & .66 & .53 & $.42 *$ \\
\hline 22 & $\begin{array}{l}\text { Başarılı olup olmamam kendimden çok } \\
\text { başkalarına bağlı }\end{array}$ & & .60 & .43 & $.38 *$ \\
\hline 14 & $\begin{array}{l}\text { Çok iyi bir destek almıyorsan (özel ders, } \\
\text { dershane, etüt... gibi) asla başarılı olmazsın }\end{array}$ & & 60 & 41 & $.37 *$ \\
\hline 6 & $\begin{array}{l}\text { Eğer başarılı olursam bu benim başarımdan çok } \\
\text { sınavın çok kolay olması ile ilgilidir } \\
\text { "Mükemmeliyetçilik" }\end{array}$ & & .59 & .41 & $.34 *$ \\
\hline 7 & Girdiğim her sınavda en iyisi olmalıyım & & .78 & .65 & $.44 *$ \\
\hline 23 & Sınavlarda mutlaka başarılı olmalıyım & & .70 & .64 & $.57 *$ \\
\hline 15 & Sinavlarda başarılı olmak her şeyden önemlidir & & .66 & .52 & $.49 *$ \\
\hline 8 & Başarısız olmaya asla katlanamam & & .65 & .56 & $.53 *$ \\
\hline 16 & $\begin{array}{l}\text { Kendimi ispat etmenin en iyi yolu sınavlardan } \\
\text { yüksek puan almaktır }\end{array}$ & & .58 & .50 & $.62 *$ \\
\hline
\end{tabular}

Tablo 1'de görüldüğü gibi dört boyuttan oluşan ABİBÇÖ’nün sekiz maddeden oluşan "Felaketleştirme" boyutunun maddelerinin faktör yükü .55 ile .69 arasında, altı maddeden oluşan "Benlik değeri" boyutunun madde faktör yükü .52 ile .79 arasında, altı maddeden oluşan "Dışa atıf" boyutunun madde faktör yükü .59 ile .73 arasında ve beş maddeden oluşan "Mükemmeliyetçilik" boyutunun ise madde faktör yükleri .58 ile .78 arasında değişmektedir. Bununla birlikte maddelerin ortak faktör varyansının .34 ile .66 arasında; madde toplam korelasyonun ise .30 ile .68 arasında değiştiği belirlenmiştir.

ABİBÇÖ'nün alt boyutları arasında çoklu bağıntı sorunu olup olmadığını belirlenmesi amacıyla alt boyutların birbiri korelasyonları incelenmiştir. Tabachnick ve Fidell (2015) değişkenler arasında çok yüksek korelasyonun (.90 ve üstü) varlığının çoklu bağıntı sorununa işaret olduğunu ifade ederler. Kline (2005) ise korelasyon değerinin .85 üstü olmasının çoklu bağıntı sorunun göstergesi olduğunu bildirir. Aşağıda tablo 2'de ölçek ve alt boyutları arasındaki korelasyon değerleri, aritmetik ortalama, standart sapma değerleri verilmiştir. 
Tablo 2.

ABİBÇÖ ve Alt Boyutlarının Aritmetik Ortalama, Standart Sapma ve Korelasyonlar Değerleri

\begin{tabular}{lccccc}
\hline & 1 & 2 & 3 & 4 & 5 \\
\hline 1. Felaketleştirme & - & & & & \\
2. Benlik değeri & $.44^{*}$ & - & & & \\
3. Dişa atıf & $.30^{*}$ & $.26^{*}$ & - & & \\
4. Mükemmeliyetçilik & $.55^{*}$ & $.27^{*}$ & $.16^{*}$ & - & \\
5. Ölçek toplam & $.87^{*}$ & $.66^{*}$ & $.55^{*}$ & $.72^{*}$ & - \\
\hline$\overline{\mathrm{x}}$ & 22,08 & 10,32 & 10,70 & 14,28 & 57,38 \\
$\mathrm{Ss}$ & 6,47 & 3,83 & 3,78 & 4,57 & 13,53 \\
\hline
\end{tabular}

$* \mathrm{p}<.01$

Tablo 2'de görüldüğg̈ü üzere alt boyutlar arasında .16 ile .55 arasında bir korelasyon değeri görülmektedir $(\mathrm{p}<.01)$. Bu değer alt boyutlar arasında çoklu bağıntı sorunu olmadığına işarettir (Kline, 2005; Tabachnick ve Fidell, 2015). Diğer taraftan alt boyutların ölçeğin geneli ile olan korelasyon değerleri incelendiğinde en yüksek ilişkinin faktör bir ile $(r=.87 ; \mathrm{p}<.01)$, en düşük ilişkinin ise faktör üç ile $(\mathrm{r}=.55 ; \mathrm{p}<.01)$ olduğu görülmektedir.

Bir ölçeğin geçerliğine ilişkin önemli kanıtlardan biri de açıklanan varyanstır. Tablo 3'te ölçeğin ve alt boyutların öz değerleri ve açıkladıkları varyans değerleri verilmiştir.

Tablo 3.

Ölçeğin ve Alt Boyutlarının Öz Değerleri ve Açıkladığı Varyans Yüzdesi

\begin{tabular}{lll}
\hline & Öz değer & Açıklanan varyans (\%) \\
\hline 1. Felaketleştirme & 6,39 & 14,83 \\
2. Benlik değeri & 2,69 & 13,48 \\
3. Dişa atıf & 2,10 & 11,42 \\
4. Mükemmeliyetçilik & 1,54 & 11,15 \\
\hline ABİBÇÖ (Toplam) & & 50,87 \\
\hline
\end{tabular}

Tablo 3'te görüldüğü üzere ölçeğin dört boyutunun öz değeri 1,54 ile 6,39 arasında; açıkladıkları varyans ise \%11,15 ile \%14,83 arasında değişmekteyken dört alt boyutun açıkladığı toplam varyans ise $\% 50,87$ 'dir. Tavşancıl (2002) sosyal bilimlerde tutumları ölçmeye yönelik geliştirilen ölçme araçlarında \%40 ile \%60 arasında açıklanan varyansın yeterli olacağını; Büyüköztürk (2010) ise tek boyutlu ölçeklerde \%30; çok boyutlu ölçeklerde ise açıklanan varyansın daha yüksek olması gerektiğini ifade eder. Bu kriterler çerçevesinde ABİBÇÖ’nün açılanan yaryansının yeterli olduğu söylenebilir.

\section{Doğrulayıcı faktör analizi (DFA)}

ABİBÇÖ'nün geçerliğine dair daha fazla kanıt elde etmek ve AFA sonucunda oluşan dört faktörlü 25 maddeli yapının farklı bir örneklem grup üzerinde doğrulanıp doğrulanmayacağının belirlenmek amacıyla DFA yapılmıştır. Doğrulayıcı faktör analizi daha önceden belirlenmiş teorik bir yapının veri tarafından doğrulanıp doğrulanmayacağına ilişkin kanıtların arandığı analizlerdir (Byrne, 2010; Kline, 2005; Meydan ve Şeșen, 2011; Ullman, 2001). Maximum Likelihood (En çok olabilirlik) tekniği ile yapılan doğrulayıcı faktör analizi sonuçlarının değerlendirilmesinde madde faktör yükleri, uyum iyiliği ve t değerleri kullanılmıştır.

Doğrulayıcı faktör analizinde model veri uyumunu değerlendiren en önemli ölçütlerden biri uyum iyiliği değerleridir, çünkü her bir modelin bir bütün olarak veri tarafindan kabul edilir düzeyde doğrulanıp doğrulanmadığına ilişkin fikir edinmemize yardımcı olurlar (Şimşek, 2007). Ullman (2001) birbirinden farklı uyum iyiliği değerlerinin büyük oranda araştırmacıyı benzer sonuçlara ulaştırdığını ifade ederek hangi uyum iyiliği değerinin kullanılacağının büyük oranda kișisel tercihlere bağlı olduğunu ifade eder. Bu çalıșmada kullanılan uygum iyiliği değerleri, bu değerlere ilişkin kesme noktaları ve ABİBÇÖ ölçeğinden elde edilen uyum iyiliği değerleri tablo 4'te gösterilmiştir. 
Tablo 4.

Uyum İndisleri ve ABİBÇÖ’nün Verilerinin Uyum İyiliği Değerleri

\begin{tabular}{llcccccc}
\hline Model & \multicolumn{2}{l}{ Model veri uyum indisleri (kabul edilebilir kesme noktalar1) } & \\
& $X^{2} /$ sd $(\leq 5)$ & $\begin{array}{l}\text { RMSEA } \\
(\leq .05-.08)\end{array}$ & $\begin{array}{l}\text { CFI } \\
(\geq .90)\end{array}$ & $\begin{array}{c}\text { NNFI } \\
(\geq .90)\end{array}$ & $\begin{array}{c}\text { SRMR } \\
(\leq .10)\end{array}$ & Sonuç \\
\hline $\begin{array}{l}\text { Tek } \\
\text { faktörlü } \\
\text { model }\end{array}$ & $1661,40 / 275=4,22$ & .12 & .92 & .91 & .09 & Model ret edilir \\
$\begin{array}{l}\text { Dört } \\
\text { faktörlü } \\
\text { model }\end{array}$ & $617,42 / 269=2,29$ & .08 & .95 & .95 & .08 & $\begin{array}{c}\text { Mevcut } \\
\text { modellerde en } \\
\text { iyi uyum }\end{array}$ \\
$\begin{array}{l}\text { II. Düzey } \\
\text { DFA } \\
\text { modeli }\end{array}$ & $756,77 / 271=2,79$ & .09 & .94 & .93 & .09 & Kabul edilebilir \\
\hline
\end{tabular}

Tablo 4'te görüldüğü üzere DFA analizinde farklı modellerin uyum iyiliği değerleri incelenmiş (Yurdugül ve Sarıkaya-Alsancak, 2013) ve her bir uyum iyiliği değerine ait kabul edilebilir kesme noktaları uyum iyiliğinin altında parantez içinde verilmiştir. Doğrulayıcı faktör analizinde ilk olarak ölçeğin tek boyutlu olup olmadığının sınanması için "tek faktörlü model", ikinci olarak AFA sonucunda elde edilen "dört faktörlü model" ve son olarak dört faktörlü yapının ortak bir yapı altında toplandığ "ikinci düzey DFA" modeli sınanmıştır. Sınanan modellerden tek faktörlü model RMSEA değeri (.12) kabul edilebilir sınırların dışına çıktığı için ret edilmiştir. İkinci düzey DFA modelinde ise RMSEA dışında elde edilen uyum iyiliği değerleri kabul edilebilir sınırların içindedir ancak Çelik ve Yılmaz (2013) .10 altı RMSEA değerinin zayıf da olsa kabul edilebilir bir değer olduğunu ifade etikleri için bu model "kabul edilebilir" model olarak sonuçlandırılmıştır. Sınanan diğer bir model olan dört faktörlü modelde $X^{2} /$ sd, CFI ve NNFI değerleri mükemmel uyumu (Byrne, 2010; Kline, 2005; Meydan ve Şeșen, 2011; Ullman, 2001) SRMR vasat uyumu (Kline, 2005), RMSEA ise yeterli uyumu (Çelik ve Yılmaz, 2013) gösterdiğinden mevcut modeller içerisinde en iyi model veri uyumunun bu yapıda olduğu görülmüştür.

Uyum iyiliği değerlerinin yanında DFA sürecinde incelenen önemli değerlerden biri ölçekteki her bir maddenin faktör yükleri ve alt boyutlar arasındaki ilişkilerdir. Yapılan analiz sonucunda ulaşılan standardize edilmiş madde faktör yükleri ve alt boyutlar arasındaki ilişkiler Şekil 2'de sunulmuştur 


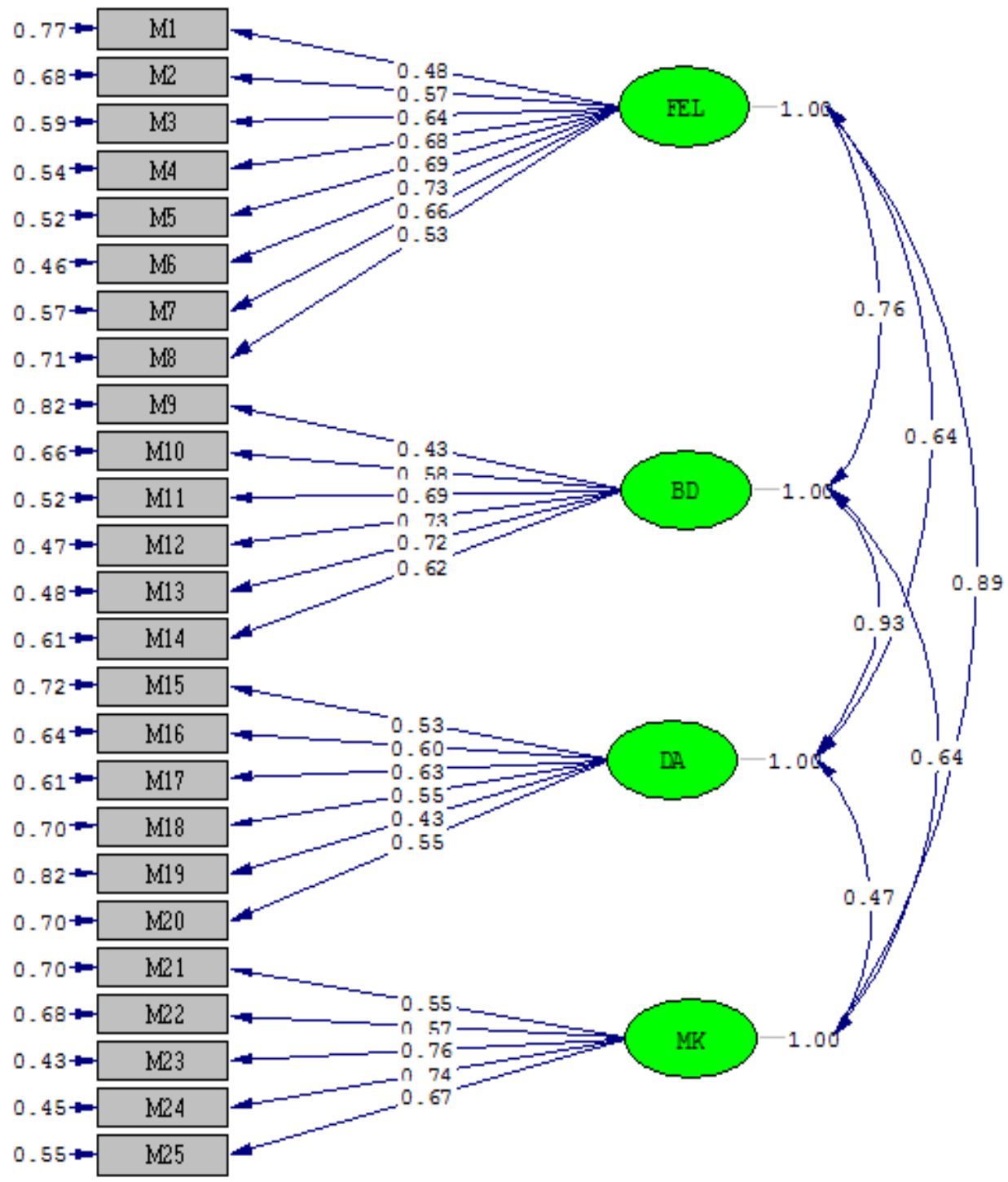

Chi-Square $=617.42, \mathrm{df}=269, \mathrm{P}$-value $=0.00000, \mathrm{RMSEA}=0.077$

Şekil 2. Standardize Edilmiş Madde Faktör Yükleri ve Alt Boyutlar Arasındaki İlişkiler

Şekil 2'de görülüğü üzere maddelerin yer aldıkları boyuttaki faktör yükleri Felaketleştirme (FEL) boyutunda .48 ile .73 arasında; Benlik değeri (BD) boyutunda .43 ile .73 arasında; Dışa atıf (DA) boyutunda .43 ile .63 arasında ve Mükemmeliyetçilik (MK) boyutunda ise .55 ile .76 arasında değişmektedir. Bununla birlikte maddelerin bulundukları faktördeki t değerlerinin 6,05 ile 12,37 arasında değiştiği ve tüm maddelerin modele anlamlı katkı sağladığı görülmüştür $(\mathrm{p}<.01)$.

\section{Ölçmenin güvenirliğine ilişkin bulgular}

Ergenlerin akademik başarıya ilişkin bilişsel çarpıtmalarını belirlemeyi amaçlayan ABİBÇÖ'nin güvenirlik çalışmaları dört yöntemle yapılmıştır. Bu yöntemler ölçeğin bütününe ve alt boyutlarına ilişkin hesaplanan Cronbach's Alfa iç tutarlılık analizi, test tekrar test analizi ve yapısal güvenirlik analizi şeklindedir. Aşağıda Tablo 5'te ölçeğin güvenirlik analizine ilişkin değerler sunulmuştur. 
Tablo 5.

ABİBÇÖ’nün Cronbach's Alfa, Yapısal Güvenirlik ve Test Tekrar Test Analizi Değerleri

\begin{tabular}{lccc}
\hline & Alfa & $\begin{array}{c}\text { Yapısal } \\
\text { Güvenirlik }\end{array}$ & Test tekrar test \\
\hline Felaketleştirme & .82 & .84 & .85 \\
Benlik değeri & .84 & .80 & .82 \\
Dişa atıf & .80 & .72 & .75 \\
Mükemmeliyetçilik & .78 & .79 & .72 \\
ABİBÇÖ (Toplam) & .89 & .94 & .89 \\
\hline
\end{tabular}

Tabloda görüldüğü üzere ölçeğin Cronbach's Alfa iç tutarlılık değerleri alt boyutlar bazında .78 ile .84 arasında, toplam ölçek iç tutarlılık değeri ise .89 olarak bulunmuştur. Ölçeğin zamana karş1 ölçüm güvenirliğini belirlemek için 48 lise öğrencisine araç 22 gün arayla iki defa uygulanan formda iki uygulama arasında faktör bazında .72 ile .85 arasında bir korelasyon bulunurken; ölçeğin geneli için .89 düzeyinde bir ilişki belirlenmiştir. Yapısal güvenirliğe ilişkin yapılan analizlerde alt boyutlarda .72 ile .84 arasında değerler bulunurken, ölçeğin genelinin yapısal güvenirliği .94 olarak tespit edilmiştir.

\section{Ölçeğin uygulamasını standartlaştırma}

Orta öğretim kurumlarına devam eden öğrencilerin akademik başarıya ilişkin bilişsel çarpıtmalarını değerlendirmek amacıyla geliştirilen ölçme aracının yönergesinde öğrencilere formu nasıl dolduracakları, çalışmanın amacı, bilgilerinin gizli kalacağı ve çalışmaya katılımın gönüllülüğü hakkında bilgi verilir. Beşli likert tipi derecelendirme ile puanlanan hiç katılmıyorum (1), katılmıyorum (2), biraz katılıyorum (3), katılıyorum (4), tamamen katıliyorum (5), araçtan alınan puanın yükselmesi kişinin bilişsel çarpıtma düzeyinin yükseldiğinin göstergesidir. Ters puanlanan (reverse) herhangi bir maddenin bulunmadığı ABİBÇÖ’den alınabilecek en yüksek puan 125 , en düşük puan ise 25 'tir. Bu çalışmada AFA kapsamında toplanan verilerin aritmetik ortalaması 57,38 standart sapması ise 13,53'tür. Dört alt boyuttan oluşan aracın başarısızlı̆ 1 felaketleştirme ile ilgili ifadeleri içeren "Felaketleştirme" boyutu "1, 2, 9, 10, 17, 18, 24, 25"; kişisel değerini başarı üzerinden tanımlayan maddeleri içeren "Benlik değeri" boyutu " $3,4,11$, 12, 19, 20"; başarı veya başarısızlığı kendi dışındaki etmenlerde arayan "Dışa atıf" boyutu: " 5,6 , $13,14,21,22$ " ve son olarak başarıya dair katı ve yüksek standartları içeren "Mükemmeliyetçilik” boyutu: "7, 8, 15, 16, 23” maddelerinden oluşmaktadır.

\section{Tartışma / Sonuç ve Öneriler}

Bilişsel terapi kuramsal çerçevesinden hareketle orta öğretim öğrencilerinin akademik başarıya ilişkin bilişsel çarpıtmalarını ölçecek geçerli ve güvenilir bir ölçme aracı geliştirmeyi amaçlanmıştır. Güvendir ve Özkan (2015) ile Şeker ve Gençdoğan (2006) ölçek geliştirme çalışmalarında literatürden, hedef grupla görüşmelerden ve uzman görüşlerinden hareketle madde havuzu oluşturmasının gerekli olduğunu ifade ederler. Bu kapsamda; çalışmada ilk olarak kuramsal temeller, öğrenci görüşmeleri, benzer ölçekler gibi kaynaklardan yararlanılarak 55 maddeli bir madde havuzu oluşturulmuştur. İkinci şamada ise madde havuzundaki ifadelerle ilgili uzman görüşü alınıp gerekli düzenlemeler yapılarak ölçeğin 52 maddeli ilk formu oluşturulmuştur.

Çok sayıda ölçek maddesi ile başlanan ölçek geliştirme çalışmalarında daha az sayıda ve tutarlı maddelerden oluşan yapılar elde etmeyi amaçlayan faktör analizi (Pallant, 2016) tekniği ile ABİBÇÖ'nün maddelerine AFA yapılmıştır. Yapılan AFA'da ölçekte 13 boyuttan oluşan bir yapı belirlenmesinden dolayı anlaşılırlığı kolaylaştırmak için daha az sayıda faktöre ulaşılmak istenmiş ve yamaç grafiği incelendiğinde dört faktörlü bir yapının olabileceği görülmüştür. Dört faktörlü yapıda bazı maddelerin yer aldıkları faktörde açıkladıkları varyansın düşük olması, bazı maddelerin ise birden fazla faktörde benzer faktör yüküne sahip olmasından (Büyüköztürk, 2010; Can, 2017; Çokluk ve diğerleri, 2010; Tabachnick ve Fidell, 2015) dolayı 25 madde, uzman 
geribildirimlerinden yola çıkarak da iki madde ölçekten çıkarılmış ve 25 maddeli bir form elde edilmiştir. İşlemeyen maddeler ölçekten çıkarıldıktan sonra veriler dört faktör ile sınırlanıp döndürülmüş ve bu işlemin sonunda oluşan yapının toplam varyansın \%50,87'sinin açıklandığı belirlenmiştir. Açıklanan bu varyans yüzdesi sosyal bilimlerde bir ölçeğin geçerliğine ilişkin yeterli bir orandır (Büyüköztürk, 2010; Tavşancıl, 2002). Ölçeğin alt boyutları isimlendirilirken ilk alt boyuttaki maddelerin başarısızlıkta mahvolacağım, rezil olurum gibi başarısızlığı felaketleştirdiği gözlendiğinden bu boyut "felaketleştirme" olarak; ikinci boyuttaki maddelerin ise başarıyı benlik değerine eş gördüğü için bu boyut "benlik değeri" olarak isimlendirilmiştir. Ölçeğin üçüncü boyutunun maddeleri incelediğinde kişinin başarı ve başarısızlığı kendi dışındaki faktörlere atfettiği gözlendiğinden bu boyut "dışa atıf"; dördüncü ve son boyut ise başarıya dair katı ve yüksek beklentiler içerdiğinden bu boyut da "mükemmeliyetçilik" olarak isimlendirilmiştir.

Açımlayıcı faktör analizi sonucu ulaşılan örtük yapının model veri uyumunun incelenmesi (Seçer, 2015) amaciyla farklı bir örneklem grup üzerinde yeniden veri toplanmış ve bu veriler üzerinde DFA yapılmıştır. DFA sürecinde üç farklı model sınanmış ve elde edilen sonuçlardan tek faktörlü model ret edilmiş, dört faktörlü model ve faktörlerin ortak bir yapıda toplandığ 1 model kabul edilmiştir. Kabul edilen modeller karşılaştırıldığında ise en iyi model veri uyumunun dört faktörlü modelde olduğu tespit edilmiştir. DFA'dan elde edilen bu sonuçlar AFA sonucu geliştirilen örtük yapının DFA ile doğrulandığını göstermektedir.

Güvenirlik bir ölçme aracının duyarlı, birbiri ile tutarlı ve kararlı ölçümler yapabilme gücüdür (Tezbaşaran, 2008). Bu çalışmada aracın güvenirliği Cronbach's Alfa, yapısal güvenirlik ve test tekrar test güvenirliği olmak üzere üç farklı yöntem ile hesaplanmıştır. Alfa güvenirliği aracın maddelerinin bir biri ile olan ilişkisi yani iç tutarlılığı/homojenliği hakkında bilgi verir (Tezbaşaran, 2008). Alfa katsayısının madde sayısına duyarlı olduğu ve madde sayısı azaldıkça güvenirlik katsayının düştügüne ilişkin eleştirileri karşılamak için alternatif bir yöntem olarak yapısal güvenirlik katsayısı hesaplanabilir (Yurdugül ve Sarıkaya-Alsancak, 2013). Bir ölçme aracının zamana karşı kararlılığını belirlemeyi amaçlayan bir analiz olan test tekrar test güvenirlik analizi ise aynı gruba bir ölçme aracının farklı zamanlarda uygulanıp iki uygulama arasındaki benzerliğin hesaplanması esasına dayanır (Seçer, 2015; Tezbaşaran, 2008). Kline (2005) güvenirlik değerlerini karşılattırılacak altın standartlar olmasa da .90 ve üzerinin "mükemmel", .80 civarının "çok iyi" .70 civarlarının ise "kabul edilebilir" güvenirlik değerleri olduğunu ifade eder. Bu çalışmadan elde edilen güvenirlik değerleri bir bütün olarak incelendiğinde .72 ile .89 arasındaki ölçümler aracın iç tutarlılık ve zamana karşı kararlılık açısından yeterli güvenirlik değerlerine sahip olduğunu göstermektedir.

$\mathrm{Bu}$ çalışmasının güçlü yanlarından biri üç farklı örneklem grup ile çalışılmış olunmasıdır. İlk çalışma grubuyla açımlayıcı faktör analizi, ikinci çalışma grubuyla doğrulayıcı faktör analizi ve üçüncü çalışma grubuyla da test tekrar test güvenirliği çalışması yapılmıştır. Bir bütün olarak bakıldığında ölçeğin geliştirilme sürecinde 606 gibi bir sayıya ulaşılması ve çalışma grubunda farklı türlerde öğrenim yapan (Mesleki ve Akademik) okul türlerinin bulunması ölçek geliştirilme sürecinde elde edilen analiz sonuçlarının yeterliliğine bir işaret olarak kabul edilebilir. Bununla birlikte ölçeğin geçerliğine ilişkin kanıtlar elde etmek için hem AFA hem de DFA kullanılması ve dört farklı güvenirlik analizi ile güvenirliğe ilişkin kanıt toplanması çalışmanın diğer bir güçlü yönü olarak düşünülebilir.

Tezbaşaran (2008) tutum ölçeklerin olumlu ve olumsuz puanlanan maddelerin bulunmasını önermektedir. Bu çalışmada maddelerin tamamının aynı yönlü puanlanıyor olması ölçme aracının bir sınırlılığı olarak kabul edilebilir. Diğer bir önemli sınırlılık ise verilerin sadece Hatay ili merkez ilçelerinden toplanmış olmasıdır. Bu noktada farklı illerde ve nispeten daha kırsal bölgelerde veri toplanıp ölçeğin geçerlik ve güvenirlik değerlerinin bu veriler üzerinden de incelenmesi bu çalışmanın bir sınırlılığını ortadan kaldırabilir. Ölçek geliştirme çalışmalarında geçerlik ve güvenirliğine ilişkin kanıtlardan biri de yeni geliştirilen ölçeğin benzer özellikleri ölçen başka bir ölçek ile ilişkisini incelemektir (Şeker ve Gençdoğan, 2006). Bu çalışmada eş değer bir form ile geçerlik güvenirliğe ilişkin kantılar elde edilmemiş olması çalışmanın diğer bir sınırlılığı olarak düşünülebilir. 
Bu çalışmadan elde edilen bulgular ABİBÇÖ’nün orta öğretime devam eden öğrencilerin akademik başarıya ilişkin bilişsel çarpıtmalarını ölçmede geçerli ve güvenilir ölçümler yapabileceğini göstermektedir. Ancak Türkiye'de orta öğretime (lise) geçişin de önemli oranda merkezi sınavlar veya akademik ortalama temelli yapıldığı göz önüne alındığında ABİBÇÖ’nün ortaokul öğrencileri üzerinde uyarlamasının yapılması alana katkı sağlayabilir. Bunun yanı sıra ruh sağlığı ve eğitim alanında çalışan uzmanlar ABİBÇÖ'yü kullanarak öğrencilerin sınavlara yüklediği anlamı belirleyebilir ve yüksek ölçek puanı alan öğrencilere ve bu öğrencilerin ailelerine yönelik müdahale stratejileri geliştirebilirler.

\section{Kaynaklar}

Ağır, M. (2007). Üniversite öğrencilerinin bilişsel çarpıtma düzeyleri ile problem çözme becerileri ve umutsuzluk düzeyleri arasındaki ilişki (Yaymlanmamış doktora tezi). Istanbul Üniversitesi, İstanbul.

Aydın, B. (1990). Üniversite öğrencilerinde depresyon, bilişsel çarpıtmalar ve akademik başarı. Marmara Üniversitesi Atatürk Ĕ̈itim Fakültesi Eğitim Bilimleri Dergisi, 2(2), 27-36.

Aydın, G. ve Aydın, O. (1990). Otomatik Düşünceler Ölçeğinin Geçerlik ve Güvenirliğii. Psikoloji Dergisi, 7(24), 51-57.

Beck, J. S. (2006). Bilişsel davranış̧̧ı terapi: temelleri ve ötesi. Nobel Akademik Yayıncılık.

Beck, J. S., Liese, B. S. ve Najavits, L. M. (2005). Cognitive therapy. R. J. Frances, S. I. Miller, ve A. H. Mack (Yay. haz.). Clinical Textbook of Addictive Disorders, içinde (ss. 474527). Guilford Press.: Penguin Group.

Boyacioglu, N. ve Kucuk, L. (2011). Irrational beliefs and test anxiety in Turkish school adolescents. The Journal of School Nursing, 27(6), 447-454.

Butler, A., Chapman, J., Forman, E. ve Beck, A. (2006). The empirical status of cognitivebehavioral therapy: A review of meta-analyses. Clinical Psychology Review, 26(1), 1731. doi./10.1016/j.cpr.2005.07.003

Büyüköztürk, Ş. (2002). Faktör analizi: Temel kavramlar ve ölçek geliştirmede kullanımı. Kuram ve Uygulamada Ë̆itim Yönetimi, (32), 470-483.

Büyüköztürk, Ş. (2010). Sosyal bilimler için veri analizi el kitabl. Ankara: Pegem Akademi.

Büyüköztürk, Ş., Çakmak, E. K., Akgün, Ö. E., Karadeniz, Ş. ve Demirel, F. (2008). Bilimsel araştırma yöntemleri. Ankara: Pegem Akademi.

Byrne, B. M. (2010). Structural equation modeling with AMOS: Basic concepts, applications, and programming. Routledge.

Savi-Cakar, F. (2014). The Effect of Automatic Thoughts on Hopelessness: Role of Self-Esteem as a Mediator. Educational Sciences: Theory and Practice, 14(5), 1682-1687.

Can, A. (2017). SPSS ile bilimsel araştırma sürecinde nicel veri analizi. Ankara: Pegem Akademi.

Childress, A. R. ve Burns, D. D. (1981). The basics of cognitive therapy. Psychosomatics, 22(12), 1017-1020.

Çelik, H. E. ve Yılmaz, V. (2013). LISREL 9.1 İle yapısal eşitlik modellemesi. Ankara: Anı Yayıncilik.

Çokluk, Ö., Şekercioğlu, G. ve Büyüköztürk, Ş. (2010). Sosyal bilimler için çok değiş̧kenli istatistik: SPSS ve LISREL uygulamalart. Pegem Akademi.

Dobson, K. S. ve Dozois, D. J. (2010). Historical and philosophical bases of the cognitivebehavorial therapies. Handbook of Cognitive-Behavioral Therapies. New York. Guilford Press.

Dryden, D., David, D. ve Ellis, A. (2009). Rational emotive behavior therapy. K. S. Dobson (Yay. haz.). Handbook of Cognitive-Behavioral Therapies. Guilford Press.

Ellis, A. (1976). The biological basis of human irrationality. Journal of individual psychology, 32(2), 145.

Ellis, A. (1979). Reason and emotion in psychotherapy. Toronto: Citadel Pres.

Erdem, A. Y. ve Bilge, F. (2008). Lise öğrencileri için meslek seçimine ilişkin akılcı olmayan inançlar ölçeği'nin geliştirilmesi. Türk Psikolojik Danışma ve Rehberlik Dergisi, 3(29), 95-114. 
Field, A. (2009). Discovering statistics using SPSS. Sage publications.

Güler, D. ve Çakır, G. (2013). Lise Son sınıf öğrencilerinin sınav kaygısını yordayan değişkenlerin incelenmesi. Türk Psikolojik Danışma ve Rehberlik Dergisi, 4(39), 82-94. doi./10.17066/pdrd.74455

Güvendir, M. A. ve Özkan, Y. Ö. (2015). Türkiye'deki eğitim alanında yayımlanan bilimsel dergilerde ölçek geliştirme ve uyarlama konulu makalelerin incelenmesi. Elektronik Sosyal Bilimler Dergisi, 14(52).

Hamamc1, Z. ve Büyüköztürk, Ş. (2003). İlişkilerle ilgili bilişsel çarpıtmalar ölçeği, ölçeğin geliştirilmesi ve psikometrik özelliklerinin incelenmesi. Çukurova Üniversitesi Eğitim Fakültesi Dergisi, 2(25), 107-111.

Kaya, İ. ve Hamamcı, Z. (2011). Anne-Babaların Akılcı Olmayan İnançları Ölçeği'nin geliştirilmesi. Educational Sciences: Theory \& Practice, 11(3), 1149-1165.

Kline, R. B. (2005). Principles and practice of structural equation modeling. Guilford Press.

Leahy, R. L. (2007). Bilişsel terapi yöntemleri. H. Türkçapar ve E. Köroğlu (Çev.). Hekimler Yayın Birliği.

Leech, N. L., Barrett, K. C. ve Morgan, G. A. (2005). Spss for intermediate statistics: use and implementation. Mahwah, NJ: Lawrence Erlbaum Associates.

MEB. (2016). Öğrenci sayısı 17 milyon 588 bine yükseldi. Erişim Tarihi: 30 Mayıs 2018, http://www.meb.gov.tr/ogrenci-sayisi-17-milyon-588-bine-yukseldi/haber/10675/tr\%20 adresinden\%2031.01.2017

Meydan, C. H. ve Şeşen, H. (2011). Yapısal eşitlik modellemesi AMOS uygulamaları. Detay Yayıncilik.

OSYM. (2017). 2017 YGS Sayısal Bilgiler. Erişim Tarihi: 29 Mayıs 2018, https://dokuman.osym.gov.tr/pdfdokuman/2017/OSYS/YGS/SAYISAL28032017.pdf

Özdel, K., Taymur, I., Guriz, S. O., Tulaci, R. G., Kuru, E. ve Turkcapar, M. H. (2014). Measuring Cognitive Errors Using the Cognitive Distortions Scale (CDS): Psychometric Properties in Clinical and Non-Clinical Samples. PLoS ONE, 9(8), e105956. doi./10.1371/journal.pone.0105956

Özer, A. K. (1990). Sinav ve sinanma kaygisı. Varlık Yayınları.

Pallant, J. (2016). SPSS kullanma kılavuzu: SPSS ile adım adım veri analizi. S. Balcı ve B. Ahi (Çev.) (6. Basım).

Putwain, D. W., Connors, L. ve Symes, W. (2010). Do cognitive distortions mediate the test anxiety-examination performance relationship? Educational Psychology, 30(1), 11-26.

Saraçli, S. (2011). Faktör analizinde yer alan döndürme metotlarının karşılaştırmalı incelenmesi üzerine bir uygulama. Düzce Üniversitesi Sağllk Bilimleri Enstitüsü Dergisi, 1(3), 22-26.

Sar1, T. ve Korkut Owen, F. (2015). The development of irrational romantic relationship beliefs inventory. International Journal of Human Sciences, 12(1), 255. doi. /10.14687 /ijhs.v12i1.3068

Savaşır, I. ve Şahin, N. H. (1997). Bilişsel-davranışçı terapilerde değerlendirme: Sık kullanılan ölçekler (C. 9). Ankara: Psikologlar derneği yayınları.

Seçer, İ. (2013). SPSS ve LISREL ile pratik veri analizi: Analiz ve raporlaştırma. Anı Yayınc1lık.

Seçer, İ. (2015). Psikolojik test geliştirme ve uyarlama süreci: SPSS ve LISREL uygulamalart. An1 yayıncilik.

Sungur, M. (1997). Bilişsel-davranışçı terapilerin gelişim öyküsü. A. Güngör (Yay. haz.), Psikoterapiler El Kitabl, içinde (ss. 50-66).

Şeker, H. ve Gençdoğan, B. (2006). Psikolojide ve eğitimde ölçme aracı geliştirme. Ankara: Nobel Yayın Dağıtım.

Şimşek, Ö. F. (2007). Yapısal eşitlik modellemesine giriş: Temel ilkeler ve LISREL uygulamaları. Ankara: Ekinoks yayınları.

Tabachnick, B. G. ve Fidell, L. S. (2015). Çok değişkenli istatistiklerin kullanımı. M. Baloğlu, (Çev.). Ankara: Nobel Akademik Yayıncilık.

Tavşancıl, E. (2002). Tutumların ölçülmesi ve SPSS ile veri analizi. Ankara: Nobel Akademik Yayıncilik. 
Tezbaşaran, A. A. (2008). Likert tipi ölçek hazırlama klavuzu (3.basım). E kitap.

Türküm, A. S. (2016). Akılcı olmayan inanç ölçeğinin geliştirilmesi* ve kısaltma çalışmaları. Türk Psikolojik Danışma ve Rehberlik Dergisi, 2(19).

Ullman, J. B. (2001). Structural equation modeling. B. G.Tabachnick ve L. S. Fidell (Yay. haz.). Using Multivariate Statistics 4th ed. Needham Heights, MA: Allyn and Bacon.

Uşaklı, H. ve Yapıcı, Ş. (2001). Grup rehberliğinin sınav kaygısına etkisi üzerine öğrenci görüşleri. Ak Ü. Sosyal Bilimler Dergisi.

Yaşlıŏlu, M. M. (2017). Sosyal bilimlerde faktör analizi ve geçerlilik: Keşfedici ve doğrulayıcı faktör analizlerinin kullanılması. İstanbul Üniversitesi İ̧letme Fakültesi Dergisi, 46, 7485.

Yurdugül, H. ve Sarıkaya-Alsancak, D. (2013). Çevrimiçi öğrenme hazır bulunuşluluk ölçeği: Geçerlik ve güvenirlik çalışması. Eğitim ve Bilim, 38(169), 391-406.

\section{Extended Abstract}

\section{Introduction}

Cognition based therapy models that are utilized in the treatment of many mental problems in a wide range from anxiety, depression to personality disorders today, were stated and promoted by Ellis and Beck starting from 60s/70s (Butler et all., 2006; Sungur, 1997). These mental health models, which accept that emotions and behaviors of the humans are associated with the thoughts rather than their subjective experiences, argue that the fundamental mechanism underlying psychological disturbances is the individual's distorted and nonfunctional thoughts (Beck, 2006). This study is based on the cognitive distortion which defined within Beck's cognitive therapy model. Cognitive distortion may be defined as the individual's thinking and perception system pertaining to a certain situation that mostly works incorrectly. People predominantly accept these statements as true without testing the reality of thinking methods or acquiring enough evidence (Childress \& Burns, 1981; Dryden, David \& Ellis, 2010.)

The students that are taking exams sometimes put meanings into tests that fall far from the real sense of being tested. Especially the idea that the test point reflects the personality of the person and failure brings about the traits as "stupid, bad child" turns the exam into a personality measurement event. If the person puts a meaning into achievement that is a lot more than its real value, that person will either push himself/herself too hard not to make a mistake or shy away from the actions that he/she is capable of, for the purpose of achieving achievement (Özer, 1990). In their study about exam anxieties, Uşaklı and Yapıcı (2001) noticed in cognitive aspect that students had some thoughts like "I am not going to be successful in the exam, it's going to get messed up after the exam, I will forget everything I know, I feel like I am incompetent, How can I explain this to my family, I will never fix again if I fail”.

In this study, it was aimed to develop a tool to assess cognitive distortions of high school students related to academic achievement and examine its psychometric properties. It is predicted that this tool to be developed is going to simplify specifically the cognitive distortions of students related to achievement and give way to intervention. Together with this, the tool is thought to facilitate preventive and healing mental health services for cognitive distortions related to academic achievement and theoretical studies related this concept.

\section{Method}

To establish item pool in this study, firstly individual and group interviews were conducted with the students that will take the higher education entrance exam, followed a pre-form was structured by examining cognitive therapy literature and scales that were developed for assess cognitive distortions. Then the expert's opinion about the pre-form was taken and a form with 52 items was obtained. The study group of the research, 340 for the exploratory factor analysis (Age: $\bar{x}=16,28$; Sd:1,07); 218 for the confirmatory factor analysis (Age: $\overline{\mathrm{x}}=15,8 ; \mathrm{Sd}: 1,40$ ) and 48 for the test retest reliability, is made up of 606 people (334 female, 269 male). Kline (2005) states that for the factor analysis, 100-200 observations are "medium", 200+ observations are "large" scale 
sample signifiers. Under these measurements, it is clear that the data set used is suitable to factor analysis both for exploratory and confirmatory factor analysis.

\section{Results}

Firstly, exploratory factor analysis (AFA) was performed on the 52 items obtained. Factors with the eigenvalue of one or more are considered as important factors in exploratory factor analysis (Büyüköztürk, 2010; Can, 2017; Yaşlığlu, 2017). The exploratory factor analysis run through the scale of this study revealed that 13 factors had more than 1 load points and these factors are explain for the $\% 61,72$ of the total variance. The fact that there were 13 factors brought the need to decrease the number of factors and while investigating screen plot it was seen that the graph became horizontal after the fourth factor, the analyses were limited to four factors using Varimax technique. 25 items were removed because they had high load value in multiple factors and some had low factor values, also 2 items were removed in accordance with expert's opinions; total of 27 items were taken out and a form including 4 factors that is explain for $\% 50,87$ of the total variance and 25 items obtained. The dimension of the tool that includes the statement of catastrophy of failure consists of 8 items and is called "Catastrophizing." while the dimension of 6 items that define the personal value through academic achievement is called "Self- value". The third dimension of the scale that is made up of 6 items is called "Outer attribution" since it is including statements that attributes the achievement or failure to the outer factors and lastly the dimension of 5 items that contains the rigid and high standards of achievement is called "Perfectionism".

To test the model fit of this four factor structure, a confirmatory factor analysis was carried out with a different study group and the findings $\left(\mathrm{X}^{2} / \mathrm{sd}=2.29\right.$; RMSEA $=.08 ; \mathrm{CFI}=.95$; $\mathrm{NNFI}=.95 ; \mathrm{SRMR}=.08)$ showed that the model has sufficient fit-indexes. Cronbach's alfa internal consistency (.89), test retest reliability (.89) and structural reliability (.94) analyses that are conducted for the reliability of the scale proved that the scale had adequate reliability values.

\section{Discussions and Conclusions}

Through the development process of this scale, within the scope of validity studies, expert opinion, EFA and CFA analyses were performed; within the scope of reliability studies, Cronbach's Alfa internal consistency, test retest reliability and structural reliability analyses were applied. The findings obtained from all the analyses above revealed that this scale of 25 items is a valid and reliable measurement tool to evaluate the cognitive distortions of high school students related to academic achievement.

A remarkable side of this study is that three different samples were worked with. Exploratory factor analysis was conducted with the first group, confirmatory factor analysis was performed in the second group and test retest reliability study was performed in the third group. From a more general view, reaching 606 people in the development process of the scale and having schools of different types (vocational and academicals) in the study group shows the adequacy of the analysis results in the scale development. Tezbaşaran (2008) suggests in attitude scales should be positive and negative scoring items. In this study, the fact that all the items are rated one-sidedly can be considered as a limitation of the measurement tool. Another important limitation is that the data is only collected from the city of Hatay, central counties. At this point, collecting data from different and preferably rural cities and examining the validity and reliability values through these data can remove a limitation of this study. 